Available online at www.refaad.com

VMPH 1(2); 2020: 72-74

Case Report

Veterinary Medicine and Public Health Journal (VMPH)

Journal Homepage: https://www.refaad.com/views/vmph/home.aspx

www.refaad.com

ISSN : 2707-7195(Online) 2707-7187(Print)

\title{
Myiasis in Free-Ranging Hedgehog (Etelerix algirus) Caused by Lucilia sericata
}

\author{
Abdulhakim A. EL Maghrbi \\ Department of Microbiology and Parasitology, Faculty of Veterinary Medicine, University of Tripoli, Tripoli, Libya. \\ Corresponding Author: Abdulhakim Abdulla EL Maghrbi (dochakim2000@yahoo.com)
}

How to cite this article: EL Maghrbi. A. Myiasis in free-ranging hedgehog (Etelerix algirus) caused by Lucilia sericata. Veterinary Medicine and Public Health Journal 1(2); 2020:72-74.

DOI: https://doi.org/10.31559/vmph2020.1.2.8

Received Date: 18/4/2020Ａccepted Date: 5/5/2020

\begin{abstract}
Lucilia sericata is an external parasite found on the animal body and cause myiasis. A case of myiasis in a hedgehog (Etelerix algirus) with many active maggots in an inflamed and bad odour wound located on upper part of neck behind the ears is described in this report. Larval stages taken from the wound were cleared and fixed. Morphological investigation revealed that the larvae were Lucilia sericata, from subfamily Calliphorinae and family Calliphoridae. To our knowledge this is a first record of myiasis in a hedgehog in Libya.
\end{abstract}

Keywords: Myiasis, Lucilia sericata; hedgehog; Libya.

\section{Introduction}

Myiasis is a pathological condition resulting from the invasion of tissues or organs of human and animals by the larval stages (maggots) of a variety of fly species of order Diptera. Myiasis is classified into obligatory (the parasite is dependent on the host for part of its life), facultative (the parasite is free living and may initiate myiasis, can develop in necrotic tissue of living animals) and accidental (free-living larva causes pathological reaction when accidentally in contact with the host). Domestic and wild mammals all over the world are commonly infested with myiasis (Abd al-Dayim et al. 2012; Akbarzadeh et al. 2012; Soleimani- Ahmadi et al. 2013). Larvae are smooth in all stages, conical-shaped and are white or yellowish through all three instars of development and reach a maximum of $12-18 \mathrm{~mm}$ before pupation. Larvae causes myiasis in both human and animals. The developmental stage takes 10-23 days. After 4 to 8 days, larvae drop on soil and transform after 6-14 days to adult flies (Talari et al. 2004; Salimi et al. 2010; Yaghoobi et al. 2005).

Hedgehogs are small mammals of Erinaceidae family (Gorgani-Firouzjaee et al. 2013; Youssefi et al. 2013; Hajipour et al. 2015). Hedgehogs are ground foraging mammals seeking invertebrates, small vertebrates and grass roots. Therefore, they are naturally exposed to haematophagous ectoparasites
(Hosni and Maghrbi, 2014). In addition, as

() (1) a host of different pathogens including bacteria, fungi and parasites (Dziemian et al. 2010; GorganiFirouzjaee et al. 2013; Youssefi et al. 2013). There is no published data about infestation of hedgehog with Lucilia in Libya. In this report, a case of myiasis in a hedgehog (Etelerix algirus) in an old infected wound located on the upper side of the neck behind the ears is described.

\section{Case report}

A free-ranging hedgehog (Etelerix algirus) was found alive in a farm located in Ain Zara region. The hedgehog was captured and clinical examination revealed a wound on the upper part of head behind and between the ears. The wound was inflamed, infected, secreted and with bad smell. By visually examination of the wound, several motile and active white warms were observed (Fig 1). A case of myiasis was diagnosed. The hedgehog was transported to the laboratory of parasitology, Faculty of Veterinary Medicine, University of Tripoli. The larvae were removed by forceps and preserved in $70 \%$ methanol. The wound was treated daily and the hedgehog was returned to the environment for free living. In the laboratory, the third larval stages cleared by lactophenol. After accurate examination by aid of 
light microscope, the larva was identified as $L$. sericata based on the morphological characters (Fig 2 and 3).

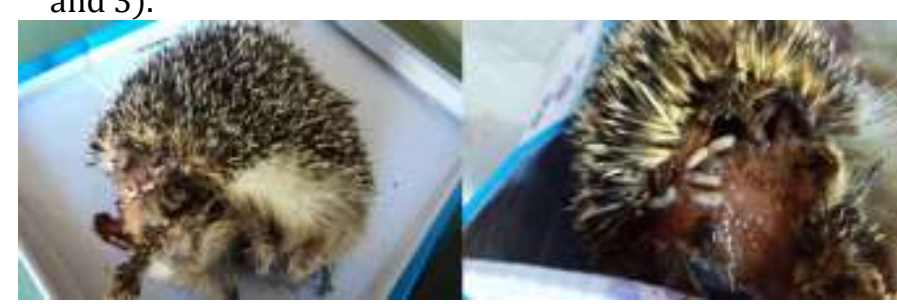

Fig (1): Larvae on the head of hedgehog

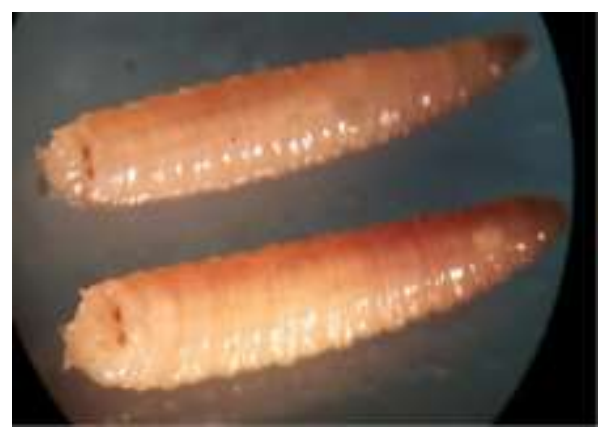

Fig (2): Third stage larvae of L. sericata

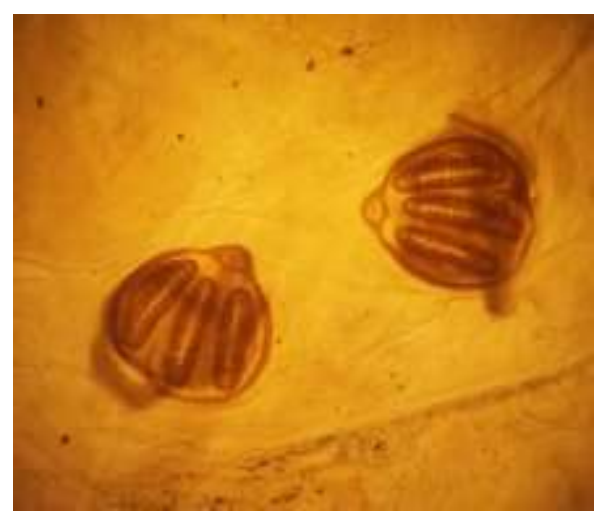

Fig (3): Stigmal plate of L. sericata

\section{Discussion}

Larval stages (maggots) of a variety of fly species, has been detected in wild animals. In the present study, myiasis was reported from a free ranging hedgehog (Etelerix algirus). The current paper reports a case of hedgehog myiasis due to $L$. sericata for the first time particularly from Libya. To ourknowledge, no previous characterization of myiasis in hedgehogs in Libya are present. Although, a case of myiasis was reported in desert hedgehog (Hemichinus aethiopicus) in Iran (Rezaei et al. 2014). Hedgehogs are hosts for a wide variety of parasites, bacteria, viruses and fungi and they can play a significant role in the transmission of some zoonotic pathogens (McCarthy and Moore, 2000; Riley and Chomel, 2005; Youssefi et al. 2011; GorganiFirouzjaee et al. 2013).

Other researchers recorded various internal and external parasites of hedgehogs in Libya. Sarcoptes scabiei, Rhipicephalus appendiculatus, Xenopsylla cheopis and Ctenocephalides canis were collected from hedgehogs (Hosni and El Maghrbi, 2014).
Hajipour et al. (2015) reported that hedgehogs also harbored flea species (Archaeopsylla erinaceid). Whereas, Nematollahi et al. (2014) found Hyalomma excavatum, Rh. Turanicus, C. canis and Leptopsylla segnis in hedgehogs in Tabriz. Additionally, helminths as Phyasaloptera clausa, Mullerius capillaries and Hymenolepis diminuta were detected (Nematollahi et al., 2014). Helminths as nematodes (Crenosoma striatum, Eucoleus aerophilus, Capillaria erinacei, C. ovoreticulata and Capillaria spp.) and trematode (Brachylaemus erinacei) were also reported. Taleb et al. (2018) identified L. sericata from 25 localities in Algeria. Also, show that $L$. sericata occurs in warm to high temperatures and widely distributed throughout Algeria in the humid, sub humid, semi-arid, and Saharan bioclimatic zones. L. sericata is a cosmopolitan fly and present throughout the world (Williams, Richards, and Villet 2014). The differences between species identified from various studies are correlated to geographical and environmental conditions. The factor such as host population densities may be influence the conquest of parasites in various regions (Thamm et al. 2009).

Conflict of interest: there is no conflict of interest.

\section{References:}

[1] Abd al-Dayim. M.M., al-Zubi. R.M., al-Isa. S.K., Katebeh-Badr. A. \& Amr. Z.S. Wound Myiasis Caused by the Common Green Bottle Fly, Lucilia Sericata: Report of a Case at the Royal Medical Services - Jordan. J. Royal Med Services, 19 (2) (2012), 82-84.

[2] Akbarzadeh. K., Rafinejad. J., Alipour. H. \& Biglarian. A. Human Myiasis in Fars Province, Iran. Southeast Asian J Trop Med Public Health, 43 (5) (2012),1205-11.

[3] Dziemian. S., Pilacinska. B., Bogawski, P. \& Michalik. J. Infestation of the Northern whitebreasted hedgehog (Erinaceus roumanicus) with Ixodes ticks in urban ecosystems of the city of Poznan. Arthropods. Ecological and pathological aspects of parasite-host relationship. Buczek Alicja, Blaszak Czeslaw (eds.), Akapit, Lublin, (2010): 41-47.

[4] Gorgani-Firouzjaee. T., Pour-Reza. B., Naem. S. \& Tavassoli. M. Ectoparasitic infestations of the European hedgehog (Erinaceus europaeus) in Urmia city, Iran: First report. Vet Res Forum, 4 (3) (2013), 191- 194.

[5] Hajipour. N., Tavassoli. M., Gorgani-Firouzjaee. T., Naem. S. Pourreza. B., Bahramnejad. K. \& Arjmand. J. Hedgehogs (Erinaceus europaeus) as a Source of Ectoparasites in Urban-suburban Areas of Northwest of Iran. Iran J Arthropod Borne Dis, 9 (1) (2015), 98-103.

[6] Hosni. MM. \& El Maghrbi. AA. Ectoparasites infestation of free-ranging hedgehog (Etelerix algirus) in north western Libya, Open Vet J, 4 (1) (2014), 12-15. 
[7] McCarthy. J. \& Moore. TA. Emerging helminth zoonoses, Int J Parasitol, 30 (12-13) (2000), 1351-1360, https://doi.org/10.1016/s00207519(00)00122-3

[8] Nematollahi. A., Ashrafi Helan. J., Golezardy. H., Zaboli. N., Nouruzi. M. \& Azari. M. Parasitic Fauna of East European Hedgehog (Erinaceus Concolor) and Their Pathological aspects in Iran. Adv Zool Bot, 2 (1) (2014), 1-5.

[9] Rezaei. M., Sabzevari. S., Fard Saied. SRN \& Saber. M. Myiasis (Lucilia sericata) in a desert hedgehog (Hemichinus aethiopicus). Online J Vet Res, 18 (11) (2014), 900-904, 2014.

[10] Riley. PY. \& Chomel. BB. Hedgehog zoonoses, Emerg Infect Dis, 11(7) (2005) 1-5, https://doi.org/10.3201/eid1101.040752

[11] Salimi. M., Goodarzi. D., Karimfar. M. \& Edalat. H. Human Urogenital Myiasis Caused by Lucilia sericata (Diptera: Calliphoridae) and Wohlfahrtia magnifica (Diptera: Sarcophagidae) in Markazi Province of Iran. Iran J Arthropod borne Dis, 4 (1) (2010), 72-76.

[12] Soleimani-Ahmadi. M., Vatandoost. H., HanafiBojd. AA., Poorahmad-Garbandi. F., Zare. M. \& Hosseini. SMV. First Report of Pharyngostomy Wound Myiasis Caused by Chrysomya bezziana (Diptera: Calliphoridae) in Iran. Iran J Arthropod-Bor Dis, 7 (2) (2013), 194-198.

[13] Talari. S., Sadr. F., Doroodgar. A., Talari. MR. \& Gharabagh. AS. Wound Myiasis Caused by Lucilia Sericata. Arch Iran Med, 7 (2) (2004), 128-129.
[14] Taleb. M., Tail. G., Açıkgöz. HN., Djedouani. B. \& Toumi. M. First data on the distribution of Lucilia sericata Meigen, Calliphora vicina RobineauDesvoidy and Chrysomya albiceps Wiedmann (Diptera, Calliphoridae) in Algeria, Zool Ecol, (28) (2) (2018),142-154, https://doi.org/10.1080/21658005.2018.1462611

[15] Thamm. S., Kalko. EKV. \& Wells. K. Ectoparasite Infestations of Hedgehogs (Erinaceus europaeus) are Associated with Small-Scale Landscape Structures in an Urban-Suburban Environment. Eco Health, 6(3) (2009), 404 413, https://doi.org/10.1007/s10393-009-0268-3

[16] Yaghoobi. R., Tirgari. S. \& Sina. N. Human Auricular Myiasis Caused by Lucilia Sericata: Clinical and Parasitological Considerations. Acta Med Iran, (43) (2) (2005), 155-157.

[17] Youssefi. MR., Rahimi. MT., Halajian. A., Moosapour. AA., Nikzad. R., Nikzad. M., Ramezanpour. S. \& Ebrahimpour. S. Helminth Parasites of Eastern European Hedgehog (Erinaceus concolor) in Northern Iran. Iran J Parasitol, 8 (4) (2013), 645-650.

[18] Youssefi. MR., Rahimi. MT., Hosseini. SM. \& Darvishi. MM. First Report of Rhipicephalus turanicus from Hedgehog (Erinaceus concolor) in North of Iran. World J Zool, 6 (4) (2011), 401403.

[19] Williams. K.A., Richards. CS. \& Villet. MH. Predicting the Geographic Distribution of Lucilia sericata and Lucilia cuprina (Diptera: Calliphoridae) in South Africa. African Invertebrates, 55 (1) (2014),157-170. 